\title{
E-GOVERNANCE PHASED SECURITY MODEL
}

\author{
Vani Jain \\ Research Scholar, Department of Computer Science \& Engineering, \\ Suresh Gyan Vihar University, Jaipur, India \\ Dr. Devesh Bandil \\ Associate Professor, Department of Computer Science \& Engineering, \\ Suresh Gyan Vihar University, Jaipur, India \\ Dr. Bright Keswani \\ Professor, Department of Computer Science \& Engineering, \\ Suresh Gyan Vihar University, Jaipur, India

\section{Neha Paliwal} \\ Research Scholar, Department of Computer Science \& Engineering, \\ Suresh Gyan Vihar University, Jaipur, India
}

\begin{abstract}
E-Governance is basically the use of internet expertise as a tool for exchanging information, providing services and transacting with people, businesses and other areas of government. E-Governance provides a sound approach to reinforce overall governance. It not only perk up accountability, intelligibility and effectiveness of government processes, but also smooth the progress of sustainability and inclusive growth. E-Governance also provides an instrument of straight delivery of public services to the trivial segments of the society in the remotest corners, without having to deal with mediators. This paper deals with analysis of the existing models and find out threats at each level and develop a new model to overcome these threats.
\end{abstract}

Key words: e-governance, security service, authentication, e-services, threats.

Cite this Article: Vani Jain, Devesh Bandil, Bright Keswani and Neha Paliwal, E-Governance Phased Security Model, International Journal of Management (IJM), 11(12), 2020, pp. 3224-3232.

http://iaeme.com/Home/issue/IJM?Volume=11\&Issue=12

\section{INTRODUCTION}

The idea of e-government started with the introduction of government websites in the early 1990s. The structure of government is flat, fixed hierarchical regulated, whereas web is dynamic, smooth and unregulated. Government's function is like enormous, where one hand 
does not know what the right hand is doing. With the advancement of Information Technology and increased reliance on the internet as a transaction medium to develop government websites into a highly potential channel for supporting a frontend and backend applications. Egovernment security is a key dilemma for every E-government systems. E-Government security models are used in the implementing and developing e-government security systems. The diverse security models are applied in different countries due to the deference situation of the countries. The five different models of e-governance, which can be applied for e-governance security system.

These models are:

Table 1

\begin{tabular}{|c|c|}
\hline MODELS & DESCRIPTION \\
\hline Broadcasting model & $\begin{array}{l}\text { - Broadcasting model is a mass diffusion of } \\
\text { government information which is already } \\
\text { available in the public sphere using ICTs. } \\
\text { This raises responsiveness among the society } \\
\text { about ongoing government processes and } \\
\text { government services that are available to them } \\
\text { and how they can advantage from them. }\end{array}$ \\
\hline Comparative Analysis Model & $\begin{array}{l}\text { This model is least-used but a high potential e- } \\
\text { governance model for developing countries. This } \\
\text { model is used to authorize people by comparing } \\
\text { good governance with the bad governance and } \\
\text { then analyze, the reasons and people behind the } \\
\text { bad governance, and how the condition can be } \\
\text { improved. } \\
\text { The model is based on using vast capacity of ICT } \\
\text { and social media to review the information given } \\
\text { with comparable information available in the } \\
\text { public or private sector. }\end{array}$ \\
\hline Critical flow model & $\begin{array}{l}\text { - The model is based on dissemination of } \\
\text { information of 'critical' value to targeted viewers } \\
\text { using ICTs and other tools. } \\
\text { - Those who reveal such kind of information } \\
\text { include upright officials and workers, } \\
\text { whistleblowers, affected parties and those who } \\
\text { were themselves involved in bad governance } \\
\text { practices but have now changed their minds or } \\
\text { may wish to deal such information for soft } \\
\text { punishments. }\end{array}$ \\
\hline
\end{tabular}




\begin{tabular}{|c|c|}
\hline E-Advocacy Model & $\begin{array}{l}\text { - This is one of the most often used Digital Governance } \\
\text { model and that come to the aid of the global civil } \\
\text { society to impact on global decision-making } \\
\text { processes. } \\
\text { - The model is based on setting-up a planned, directed } \\
\text { flow of information to build strong practical allies to } \\
\text { complement actions of the real world. } \\
\text { - Virtual communities are formed which share similar } \\
\text { values and concerns, and these communities in turn } \\
\text { link up with or support real-life groups/ activities for } \\
\text { concerted action. } \\
\text { - The potency of this model is in its multiplicity of the } \\
\text { virtual community, and the ideas, expertise and } \\
\text { resources accumulated through this virtual form of } \\
\text { networking. } \\
\text { The model is able to assemble and influence human } \\
\text { resources and information beyond geographical, } \\
\text { institutional and bureaucratic barriers, and use it for } \\
\text { intensive action. }\end{array}$ \\
\hline Interactive-Service model & $\begin{array}{l}\text { - It is a consolidation of the other digital } \\
\text { governance models and opens up potential for } \\
\text { one-to-one and self-serviced participation of } \\
\text { individuals in government processes. } \\
\text { - The involvement is direct and not through } \\
\text { representatives. } \\
\text { - This model brings better objectivity and } \\
\text { simplicity in decision-making processes, and } \\
\text { provides a better feeling of involvement and } \\
\text { empowerment. } \\
\text { - Under this model, the diverse services offered by } \\
\text { the Government become directly available to its } \\
\text { citizens in an interactive Government to } \\
\text { Consumer to Government (G2C2G) channel in } \\
\text { various aspects of governance. }\end{array}$ \\
\hline
\end{tabular}

\section{THE PHASES OF E-GOVERNMENT SECURITY MODEL}

The phased structure of a model prevents our government from various categories of threats related to a single or multiple e-services. Each phase of a model will lessen the group of threats related to e-services. The five phases were selected as a part of any strong security programme. The phases are: the technical phase, the strategical phase, the proficiency phase, the operational and management phase, and the decision phase. The phases were constructed from the bottom to the top based on the importance of each level, the frequency of their implementation in government, and how they complement each other. 


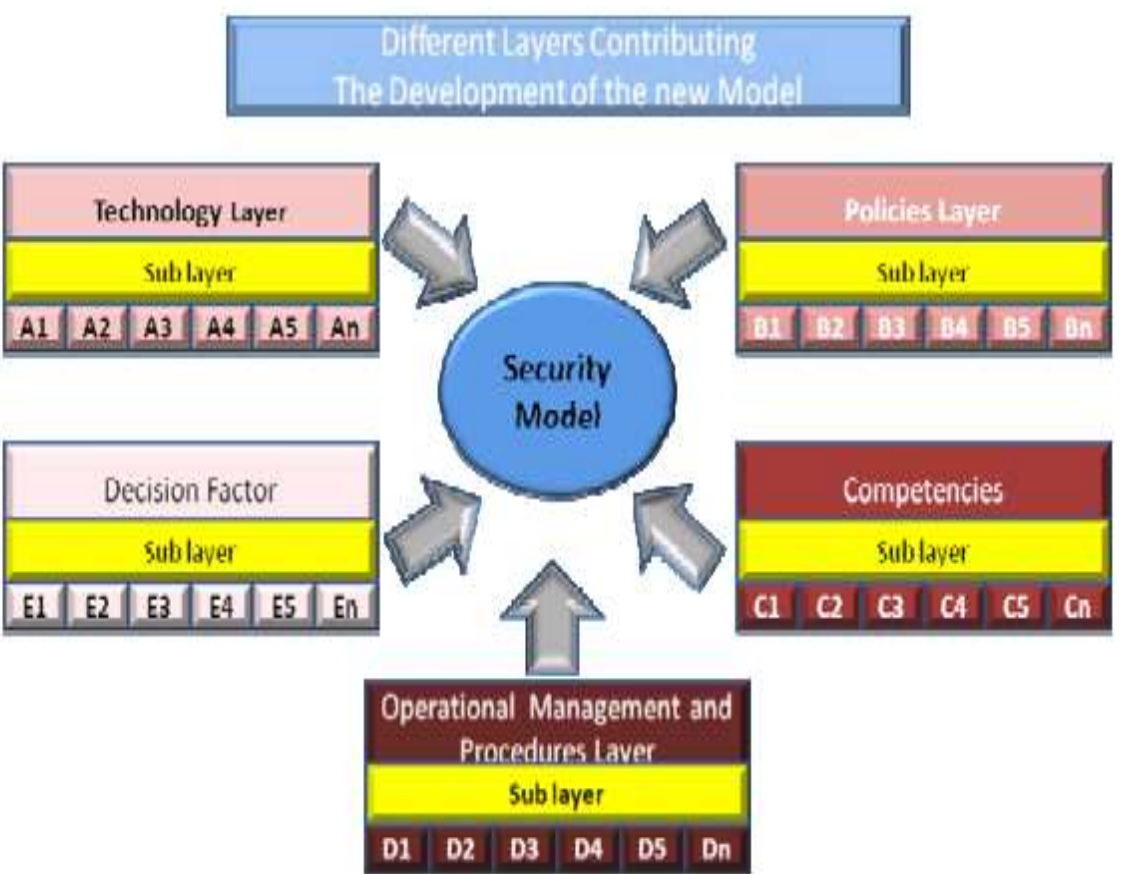

Figure 1 The five phases structuring the new security model

The concept behind this model is to analyze the security needs and requirements for any eenabled government in order to permit or not to permit the exchange of information between each other in e-government. The new abstract model is expressed as-

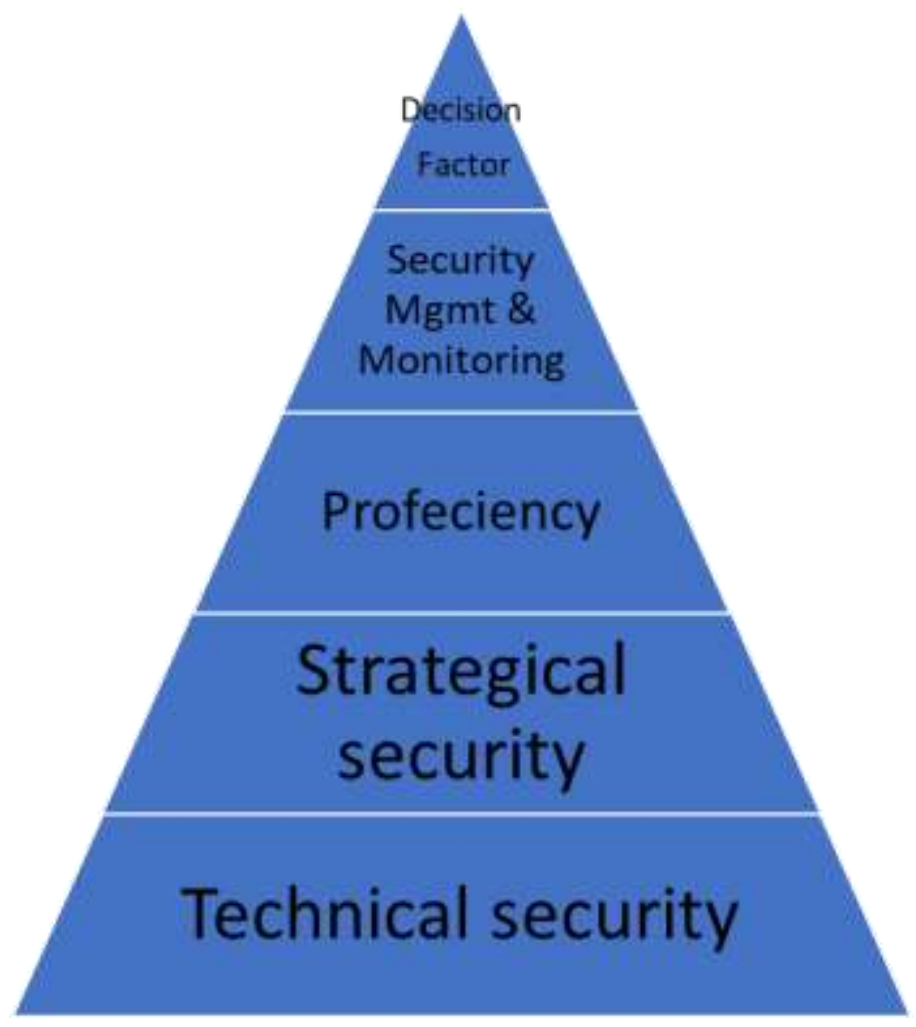

Figure 2 Pyramid phased model 
In this model every phase is sub divided into multiple sub phases to make the structure more understandable and reliable. The splitting of phases into sub phases gives the model a flexibility to expand it into n-number of cells based on the needs of the government. The idea of having $\mathrm{x}$-number of phases with $\mathrm{y}$-numbers of cells in each phase and the combination of these phases with sub-phases provide a enhanced level of security that what we considers a "new secured model" or a "new secured approach".

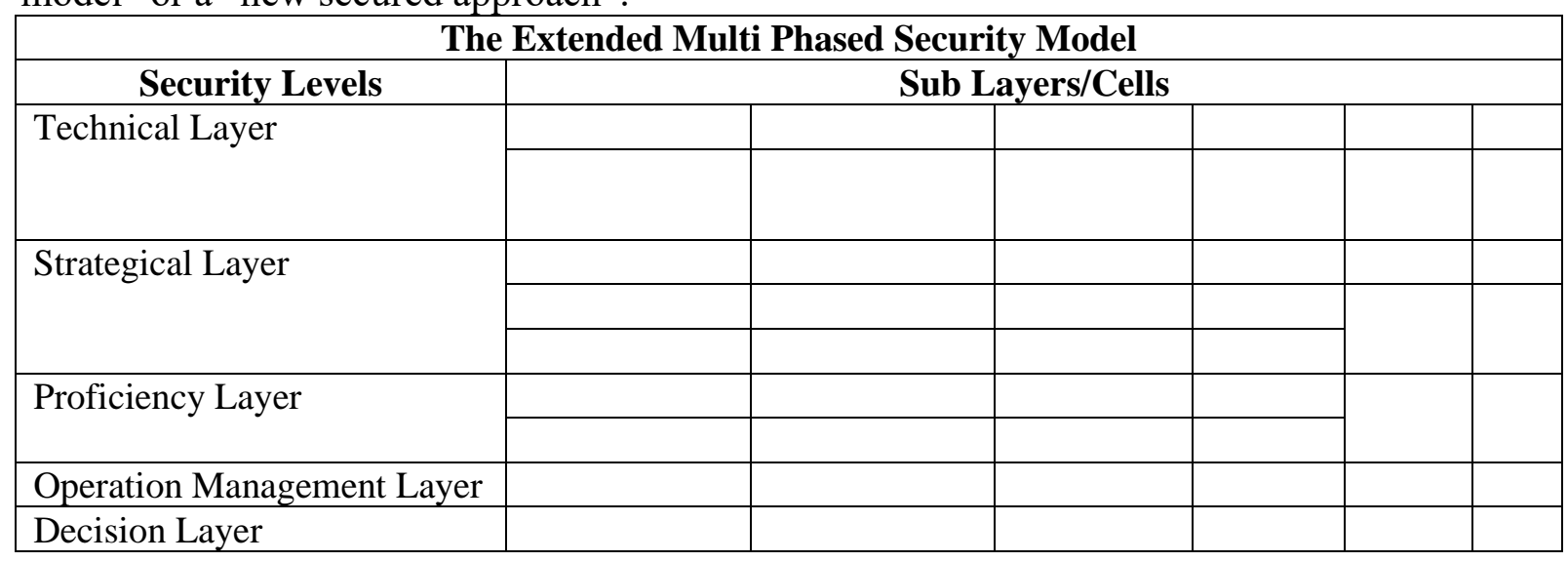

Figure 3 The matrix oriented model

\subsection{The Technical Security Phase}

The technical phase is subdivided into 12 sub phases that are as follows::

\subsubsection{Right of entry Control}

It is a mechanism of controlling entry . The control might be through prevention of unofficial entries, monitoring official entries, or limiting entries through predefined rules and roles. An egovernment model will have a strong prerequisite of access control to the computer centers where governmental data are stored, government offices where staff handles the data, and even cables that carry the data between governmental departments.

\subsubsection{Interruption detection and prevention}

Interruption detection system (IDS) and prevention system (IPS) are key elements of any security system. They ensure the safety of systems and networks. Both technologies rely on either statistical and signature databases or on the behavior of the network through Artificial Intelligence (AI) agents. Both technologies sent alerts to the authorized staff whenever there is an attack sign.

\subsubsection{Anti-virus \& malicious codes scanners}

Antivirus and malicious codes scanners are tools that perform a check on the technical body of the government and prevent viruses from being transferred through numerous channels and can cause serious damage to the government. The antivirus programs and users alertness will prevent the spread of computer viruses .

\subsubsection{Authentication and passwords}

Information system is the heart of any government. The requirement of protecting the privacy and the integrity of the information is very important. Authenticating the identity of the user is one of the fundamental factors a government needs to focus on. There is a need of 3-level security. First, Authentication through identification (password). Second, Authentication through something that they have (id card) Third, Authentication through something that is part 
of them (fingerprint).Permutation and Combination of these three factors make the authentication more accurate and hard to be searched..

\subsubsection{Files reliability checks}

Data reliability is one of the main security factors required in any government. Different tools can be used to ensure the data reliability such as digital signatures, certificates or hashing mechanism. A fall in the integrity of the data can cause a disaster if the data is related to medical, personal, or application to governmental service.

\subsubsection{Cryptography}

Cryptography is the art of hiding information from those who are not authorized to view it. Cryptography solves problems that involve secrecy, authentication and integrity. Cryptography contributes highly in building the trust of any e-government service.

\subsubsection{Virtual private network (VPN)}

VPN is becoming very popular in the today's business world. VPN services act like a tunnel to secure connection on wifi and protect your data. It play a major role in providing the staff working in supporting the e-government a mean of extending support to the infrastructure virtually, extend the work environment to the homes, and make the government information resources accessible to authorized users.

\subsubsection{Vulnerability scanning tools}

Vulnerability scanners for any security department trying to be in the proactive arena. Knowing the vulnerabilities of any government system, network, or application can add value to the security system of the government E-government will need to have scanners and tools for scanning the vulnerabilities and a group to analyze the result of these scanners.

\subsubsection{Digital signature and digital certificate}

"A signature or multiple signatures on the paper guarantee its authenticity". The digital signature is used to verify authencity, integrity, non-repudiation, i.e. it is assuring that the message is sent by the known user and not modified, while Digital Certificates on the other hand is used to verify the identity of the user, maybe sender or receiver. The main purpose of this technology is to become a main method of use in the electronic transactions in egovernment services without being forgeable

\subsubsection{Biometrics}

Biometrics is the most technical tools providing logical and physical access control to information resources. It uses metrics related to human characteristics where no duplicate can appear. It prevents imitation by matching the database of traits to the traits owners. The usage of biometrics in e-governments can vary from accessing critical systems to accessing physical restricted areas such as computer centers.

\subsubsection{Logical access control (Firewalls)}

Firewalls are logical access control mechanism allowing and jamming entries to the government network by setting up some policies An e-government with several applications will need application layer firewalls to guard the systems infrastructure and boundary firewalls to protect the admission of users from different government departments and Internet. 


\subsubsection{Security protocols}

Security protocol plays a very important task in encrypting data during its transaction from a one point to another. A table indicating all resources covering the information security technologies.

Table 2 Technical Phase

\begin{tabular}{|l|l|l|l|l|}
\hline \multicolumn{5}{|c|}{ Technical Phase } \\
\hline $\begin{array}{l}\text { A1: Right of entry } \\
\text { Control }\end{array}$ & $\begin{array}{l}\text { A2: } \\
\text { Interruption } \\
\text { Detection } \\
\text { Prevention }\end{array}$ & $\begin{array}{l}\text { A3:Anti-Virus \& } \\
\text { Malicious Codes } \\
\text { Signature }\end{array}$ & $\begin{array}{l}\text { A4:Authentication } \\
\text { and Passwords }\end{array}$ & $\begin{array}{l}\text { A5:Files } \\
\text { reliability } \\
\text { Checks }\end{array}$ \\
\hline A6: Cryptography & A7:VPN & $\begin{array}{l}\text { A8:Vulnerability } \\
\text { scanning Tools }\end{array}$ & $\begin{array}{l}\text { A9:Digital } \\
\text { Signature and } \\
\text { Certificate }\end{array}$ & A10:Biometrics \\
\hline $\begin{array}{l}\text { A11:Logical } \\
\text { Access } \\
\text { Control(firewall) }\end{array}$ & $\begin{array}{l}\text { A12:Security } \\
\text { Protocols }\end{array}$ & & & \\
\hline
\end{tabular}

\subsection{The Strategical Security Phase}

Security policies are essential for building every successful information programme. The number of security policies can differ based on the needs of the government and the area of security meant to guard against a well defined threat. These policies can increase and has no limit. The model will still hold the idea to have the right combination of policies with the other phases in the model.

Table 3 Strategical Phase

\begin{tabular}{|c|c|c|c|c|}
\hline \multicolumn{5}{|c|}{ Security Strategical Phase } \\
\hline $\begin{array}{l}\text { B1:Password } \\
\text { Management }\end{array}$ & $\begin{array}{l}\text { B2:Log-in- } \\
\text { Process }\end{array}$ & $\begin{array}{l}\text { B3:Logs } \\
\text { Handling }\end{array}$ & $\begin{array}{l}\text { B4:Computer } \\
\text { Viruses }\end{array}$ & $\begin{array}{l}\text { B5:Intellectual } \\
\text { Property Rights }\end{array}$ \\
\hline B6:Data Privacy & $\begin{array}{l}\text { B7:Privilege } \\
\text { Control }\end{array}$ & $\begin{array}{l}\text { B8:Data } \\
\text { Confidentiality }\end{array}$ & $\begin{array}{l}\text { B9:Data } \\
\text { Integrity }\end{array}$ & $\begin{array}{l}\text { B10:Internet } \\
\text { Connectivity }\end{array}$ \\
\hline $\begin{array}{l}\text { B11:Administrative } \\
\text { Policies }\end{array}$ & $\begin{array}{l}\text { B12:Encryption } \\
\text { Policies }\end{array}$ & $\begin{array}{l}\text { B13:HR } \\
\text { Security } \\
\text { Policies }\end{array}$ & $\begin{array}{l}\text { B14:Third } \\
\text { Party Policies }\end{array}$ & $\begin{array}{l}\text { B15:Physical } \\
\text { Security } \\
\text { Policies }\end{array}$ \\
\hline $\begin{array}{l}\text { B16:Operation } \\
\text { security Policies }\end{array}$ & & & & \\
\hline
\end{tabular}

\subsection{The Proficiency security Phase}

Due to the proliferation of the Internet and the usage of the citizens of the government wide eservices, government departments must invest on the human capital of the information security departments. The proficiencies listed will help the government department to enhance the security control and narrow the gap of the information between the different government security departments. It will contribute in uplifting the trust on the security programmes between the government departments and will increase the usability of the e-services by the citizens due to the strong confidence in the security level of the government departments. 
Table 4 Proficiency Phase

\begin{tabular}{|l|l|l|l|l|}
\hline \multicolumn{9}{|c|}{ Security Proficiency Phase } \\
\hline $\begin{array}{l}\text { C1:security } \\
\begin{array}{l}\text { Operation } \\
\text { Management }\end{array}\end{array}$ & $\begin{array}{l}\text { C2:Security } \\
\text { Architecture and } \\
\text { Development }\end{array}$ & $\begin{array}{l}\text { C3:Ethical } \\
\text { Hacking }\end{array}$ & $\begin{array}{l}\text { C4:Security } \\
\text { Policies } \\
\text { Development }\end{array}$ & $\begin{array}{l}\text { C5:Computer } \\
\text { Forensics }\end{array}$ \\
\hline C6:Cryptography & $\begin{array}{l}\text { C7:Security } \\
\text { programming }\end{array}$ & $\begin{array}{l}\text { C8:Laws and } \\
\text { Regulations }\end{array}$ & $\begin{array}{l}\text { C9:Security } \\
\text { Implementation } \\
\text { and Configuration }\end{array}$ & $\begin{array}{l}\text { C10:Security } \\
\text { Analysis }\end{array}$ \\
\hline
\end{tabular}

\subsection{Security operations and management Phase}

The National Institute of Standards and Technology (NIST) categorized the security controls into three categories; technical, operational, and management: Security concerns vigilant monitoring and management of critical assets and information resources. Management and operational tools are must to have in order to facilitate the security practitioner to perform the task and achieve the best objectives.

The most important facet of this phase is how the government runs its operation. The operational policies and procedures are the rules and regulations where the security operational staff will follow in performing the tasks expected from them.. These operational policies and procedures will spell out the security policy approved in the government and shall have strong reference to it.

Table 5 Operations and management Phase

\begin{tabular}{|l|l|l|l|l|}
\hline \multicolumn{6}{|l|}{ Security Operations and Management Phase } \\
\hline $\begin{array}{l}\text { D1:Operational } \begin{array}{l}\text { Policies and } \\
\text { Procedures }\end{array} \\
\text { Tools }\end{array}$ & $\begin{array}{l}\text { D3:Correlation } \\
\text { and Data mining }\end{array}$ & $\begin{array}{l}\text { D4:Reporting } \\
\text { and response }\end{array}$ & $\begin{array}{l}\text { D5:Analysis } \\
\text { and Human } \\
\text { Intervention }\end{array}$ \\
\hline
\end{tabular}

\subsection{Decision}

Reaching the right decision for launching or not launching an e-service will have a direct impact on the success or failure of the e-service. Taking one direction or another can affect the overall model in selecting policies, technologies and hiring the right staff to run the security programme. awareness, technologies and having the appropriate staff are what construct the right combination of the security programme of any organization.

Table 6 Decision Phase

\begin{tabular}{|l|l|l|l|l|}
\hline \multicolumn{5}{|l|}{ Decision Phase } \\
\hline E1:Cost & E2:Awareness & E3:Need & $\begin{array}{l}\text { E4:Technologies } \\
\text { availability }\end{array}$ & E5:FUD \\
\hline
\end{tabular}

\section{THE MODEL EVOLUTION}

The new model will be used as a reference to identify the security levels applicable to government services. In addition, a rating process will be applied on the different phases and sub phases by a group of selected security practitioners in order to confirm the applicability of the phases/sub phases proposed in the new model. 
Table 7 Model Evaluation

\begin{tabular}{|c|c|c|c|c|c|c|}
\hline \multicolumn{7}{|c|}{ The Extended Multi Phased Security Model } \\
\hline \multirow{3}{*}{$\begin{array}{l}\text { Security } \\
\text { Levels } \\
\text { Technology } \\
\text { Phase }\end{array}$} & \multicolumn{6}{|c|}{ Sub Layers/Cells } \\
\hline & $\begin{array}{l}\text { A1: Right of } \\
\text { entry Control }\end{array}$ & $\begin{array}{l}\text { A2: Interruption } \\
\text { Detection } \\
\text { Prevention }\end{array}$ & 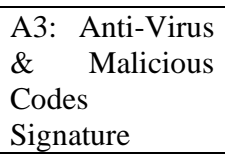 & $\begin{array}{l}\text { A4:Authentication } \\
\text { and Passwords }\end{array}$ & $\begin{array}{l}\text { A5:Files reliability } \\
\text { Checks }\end{array}$ & $\begin{array}{l}\text { A6: } \\
\text { Cryptography }\end{array}$ \\
\hline & A7:VPN & $\begin{array}{l}\text { A8:Vulnerability } \\
\text { scanning Tools }\end{array}$ & $\begin{array}{l}\text { A9:Digital } \\
\text { Signature and } \\
\text { Certificate }\end{array}$ & A10:Biometrics & $\begin{array}{l}\text { A11:Logical Access } \\
\text { Control (firewall) }\end{array}$ & $\begin{array}{l}\text { A12:Security } \\
\text { Protocols }\end{array}$ \\
\hline \multirow[t]{3}{*}{ Policy Phase } & $\begin{array}{l}\text { B1:Password } \\
\text { Management }\end{array}$ & $\begin{array}{l}\text { B2:Log-in- } \\
\text { Process }\end{array}$ & $\begin{array}{l}\text { B3:Logs } \\
\text { Handling }\end{array}$ & $\begin{array}{l}\text { B4:Computer } \\
\text { Viruses }\end{array}$ & $\begin{array}{l}\text { B5:Intellectual } \\
\text { Property Rights }\end{array}$ & B6:Data Privacy \\
\hline & $\begin{array}{l}\text { B7:Privilege } \\
\text { Control }\end{array}$ & $\begin{array}{l}\text { B8:Data } \\
\text { Confidentiality }\end{array}$ & $\begin{array}{l}\text { B9:Data } \\
\text { Integrity }\end{array}$ & $\begin{array}{l}\text { B10:Internet } \\
\text { Connectivity }\end{array}$ & \multirow[t]{2}{*}{$\begin{array}{l}\text { B11:Administrative } \\
\text { Policies }\end{array}$} & \multirow[t]{2}{*}{$\begin{array}{l}\text { B12:Encryption } \\
\text { Policies }\end{array}$} \\
\hline & $\begin{array}{l}\text { B13:HR } \\
\text { Security } \\
\text { Policies } \\
\end{array}$ & $\begin{array}{l}\text { B14:Third Party } \\
\text { Policies }\end{array}$ & $\begin{array}{l}\text { B15:Physical } \\
\text { Security } \\
\text { Policies }\end{array}$ & $\begin{array}{l}\text { B16:Operation } \\
\text { security Policies }\end{array}$ & & \\
\hline \multirow[t]{2}{*}{$\begin{array}{l}\text { Competency } \\
\text { Phase }\end{array}$} & $\begin{array}{l}\text { C1:security } \\
\text { Operation and } \\
\text { Management }\end{array}$ & $\begin{array}{l}\text { C2:Security } \\
\text { Architecture and } \\
\text { Development }\end{array}$ & $\begin{array}{l}\text { C3:Ethical } \\
\text { Hacking }\end{array}$ & $\begin{array}{l}\text { C4:Security } \\
\text { Policies } \\
\text { Development }\end{array}$ & \multirow[t]{2}{*}{$\begin{array}{l}\text { C5:Computer } \\
\text { Forensics }\end{array}$} & \multirow[t]{2}{*}{ C6:Cryptography } \\
\hline & $\begin{array}{l}\mathrm{C} 7 \text { :Security } \\
\text { programming }\end{array}$ & $\begin{array}{l}\text { C8:Laws and } \\
\text { Regulations }\end{array}$ & $\begin{array}{l}\text { C9:Security } \\
\text { Implementation } \\
\text { and } \\
\text { Configuration }\end{array}$ & $\begin{array}{l}\text { C10:Security } \\
\text { Analysis }\end{array}$ & & \\
\hline $\begin{array}{l}\text { Operation } \\
\text { Management } \\
\text { Phase } \\
\end{array}$ & $\begin{array}{l}\text { D1:Operational } \\
\text { Policies and } \\
\text { Procedures } \\
\end{array}$ & $\begin{array}{l}\text { D2:Management } \\
\text { Tools }\end{array}$ & $\begin{array}{l}\text { D3:Correlation } \\
\text { and Data } \\
\text { mining }\end{array}$ & $\begin{array}{l}\text { D4:Reporting and } \\
\text { response }\end{array}$ & $\begin{array}{l}\text { D5:Analysis and } \\
\text { Human Intervention }\end{array}$ & \\
\hline $\begin{array}{l}\text { Decision } \\
\text { Phase }\end{array}$ & E1:Cost & E2:Awareness & E3:Need & $\begin{array}{l}\text { E4:Technologies } \\
\text { availability }\end{array}$ & E5:FUD & \\
\hline
\end{tabular}

\section{CONCLUSIONS}

This paper deals with analysis of the existing models and find out threats at each level and develop a new model to overcome these threats. The concept behind this model is to analyze the security needs and requirements for any e-enabled government in order to permit or not to permit the exchange of information between each other in e-government.

\section{REFERENCES}

[1] Akers, R. L., Krohn, M. D., Lanza-Kaduce, L. and Radosevich, M. (1979), "Social learning and deviant behaviour: a specific test of a general theory", vol. 44, pp. 636- 55.

[2] Alexandros, K., Panagiotis, S., Thanos, K. and Despina, P. A secure e-government platform architecture for small to medium sized public organizations, National Technical University of Athens, Athens.

[3] Al-Hamdani, W., A. (2007), "Assessment of need and method of delivery for information security awareness program", Proceedings of the 2006 Information security Curriculum Development Conference, InfoSec CD '06, Sep 22-23 2006, Kennesaw, GA, United States, Association for Computing Machinery, New York, NY, pp. p 102-108.

[4] Anderson, A. and Shain, M. (1991), "Risk Management:", in Caelli, W., Longley, D. and Shain, M. (eds.) Information security handbook, 1st ed, Stockton Press, , pp. 75- 127.

[5] Anderson, R. (April 2001), Security Engineering: A Guide Building Dependable Distributed Systems, 1st ed, John Wiley \& Sons, Inc, U.S.

[6] Anderson. B., Homes., M.D. and Qstresh. (1999), "Male and Female Delinquent's attachment and effects of attachments on Security of Self-Reported Delinquency", Crime and Behaviour, vol. 26, no. 4, pp. 435-452. 7. Anonymous, B., Mark., Locher, L. J. and Doyle , C. (1998), Maximum Security, 1st ed, SAMS, U.S. 